\title{
Documenting Diaspora: Multiperspectivity in Sandhya Suri's Auto/Biographical Film "I for India"
}

\author{
Gabriele Linke
}

University of Rostock, Germany

\begin{abstract}
IN ENGLISH
Yash Pal Suri, a young Indian doctor, went to the UK in 1965 to complete his medical training. He equipped himself and his family back in India with a camera, tape recorder etc. so that they could film episodes of their lives and exchange 'cine-letters,' which they did for about 40 years. In 2005, Yash's daughter, Sandhya Suri, created a 70-minute documentary from her family's filmed stories and other sources, selecting and arranging the various scenes and voices recorded and combining them with clips from historical TV programmes as well as interviews and short scenes filmed between 2003 and 2005 in India and England. She re-constructs her transnational family's life story as embedded in a complex set of factors and influences. Sandhya's documentary is, on various levels, both biographical (her portrait of her family, and family members' memories of others) and autobiographical (her presence in the film, and family members talking about themselves), and these perspectives are deeply entangled. By emphasising her family's failed attempt to re-settle in India, she complicates the story of cultural integration. The result is a reconstruction of this diasporic life narrative from various angles and along the various axes of diasporic relations, especially those with home (India) and the host society (England), describing the position of the diasporic subject as in-between and continually shifting.
\end{abstract}

\section{ABSTRACT IN GERMAN}

Yash Pal Suri, ein junger indischer Arzt, ging 1965 nach Großbritannien, um dort seine klinische Ausbildung abzurunden. Er besorgte für sich und seine Familie in Indien jeweils eine Schmalfilmkamera, Tonbandgerät und Zubehör, damit sie Szenen aus dem Alltag und Gedanken aufnehmen und verschicken 
konnten, und vierzig Jahre lang tauschten sie Film-Briefe ('cine-letters') aus. 2005 produzierte Yashs Tochter, Sandhya Suri, einen 70-Minuten-Dokumentarfilm, wobei sie ausgewählte Szenen aus dem Familienarchiv mit Ausschnitten aus zeitgenössischen britischen Fernsehprogrammen sowie Interviews und kurzen Filmszenen, die sie 2003 bis 2005 in Indien und England aufnahm, kombinierte. Sie rekonstruierte die Lebensgeschichte ihrer transnationalen Familie, indem sie diese in ein komplexes Geflecht aus Faktoren und Einflüssen einbettete. Die autobiographischen und biographischen Elemente in den Filmszenen sind kaum von einander zu trennen, da der Dokumentarfilm auf mehreren Ebenen autobiographisch (ihre Präsenz im Film, auch als Regisseurin, und die Familienmitglieder über sich selbst) und biographisch (als Regisseurin über das Leben der Familie, und die Familienmitglieder übereinander) zugleich ist. Da sie den Erzählstrang der zeitweiligen Rückkehr nach Indien stark ausbaut, verhindert sie das Entstehen einer vereinfachenden Integrationserzählung. Das Ergebnis ist eine Darstellung der diasporischen Familiengeschichte aus verschiedenen Perspektiven und entlang verschiedener Achsen diasporischer Beziehungen, insbesondere der Beziehung zur Heimat (Indien) und zur aufnehmenden Gesellschaft (England), wobei diasporische Subjektivität durch eine äußerst flexible und veränderliche kulturelle Zwischenposition geprägt erscheint.

Keywords: Indian diaspora, auto/biographical documentary, multiperspectivity, myth of return

\section{"I FOR INDIA" AND THE MULTIPERSPECTIVITY OF THE MATERIAL}

The film I for India is a documentary about an Indian family divided between India and the UK. Its main protagonist and "I" is Yash Pal Suri, born in India in 1932, who studied medicine in India and, at the age of 33, arrived in the UK in 1965 to develop his professional expertise. He bought two sets of cine-cameras for Super 8 films, projectors and audio-recorders, one for himself, one for his family in India, and started an exchange of 'cine-letters' and 'audio-letters' with his family to share their lives by exchanging films rather than written texts (Fig. 1). The introduction of images and moving images with voices reflects the emotional needs on both ends to see and hear, and be seen and heard, rather than just read letters. He stayed in Britain, and for almost 40 years, from 1965 to 2005 , both he and his family back in India recorded small and big events of their lives as well as their observations and reflections on life and exchanged 'cine-letters' and/or audio-letters about their lives, 


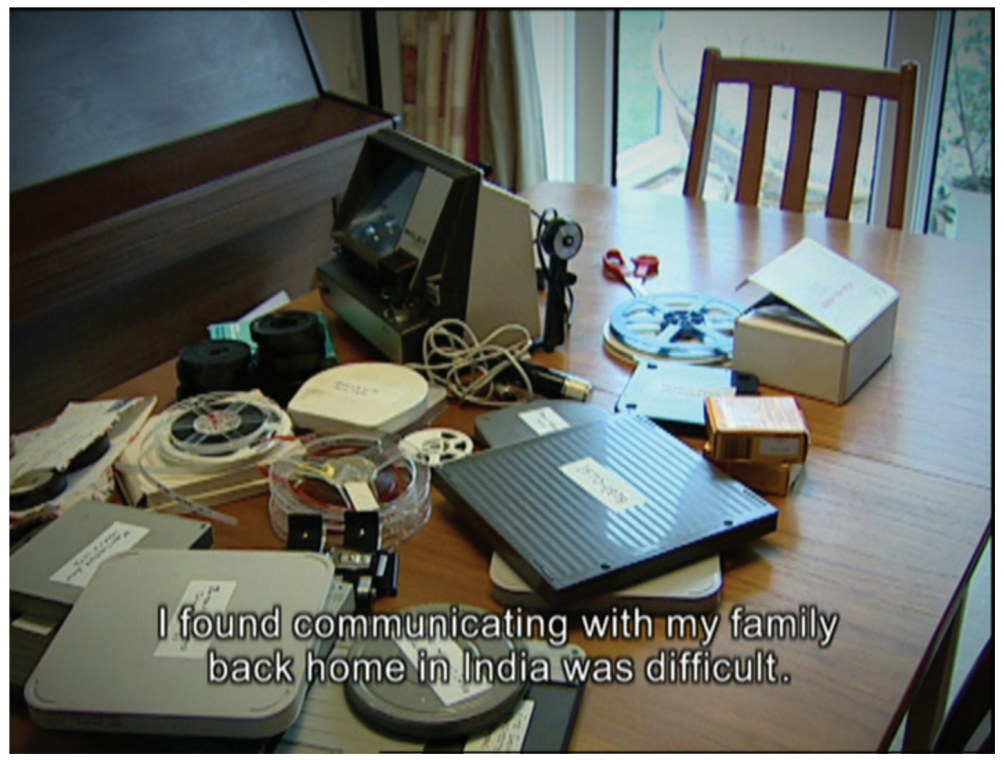

Figure 1: The filming equipment.

keeping the tapes in their private archives. Sandhya Suri, his daughter, came to share her father's fascination with filming, went to film school, became interested in her father's films and used the material for a short film, Sarfar, about the beginning of her father's story (Suri 2010, 1). Later, in the years 2001-2005, she created a 70-minute documentary from her family's filmed stories and other sources. In this film, she combined different kinds of footage, a clear understanding of which is the basis for any analysis:

1) The central body of film material for I for India is made up by the Super 8 footage Yash Pal Suri (short: Yash) and his family in India shot between 1966 and 2005. There were about 40 hours of Super 8 films from which Sandhya Suri (short: Sandhya) selected clips.

2) The audio tapes that Yash and the members of his family in India sent each other contained the most intimate self-expressions because they were recorded in private to be listened to in private.

3) Sandhya shot her own footage of her parents and other family members in England in 2001-2005 ("Film England" in the credits) on Digi-beta material colour-graded coldly (Suri 2010, 2). 
4) Additionally, German Lars Lenski filmed scenes in India on $16 \mathrm{~mm}$ film ("Film India" in the credits, for a "romantic, dreamlike feel", as Sandhya (ibid.) says) 2003-2005, because there was no Super 8 material about the Suri family's nine months' stay in India in 1982. It should be mentioned here that the film is a transnational production, with funding from ARTE, ZDF, the European Film Funds and others. Lenski only provides atmospheric shots of Indian street life as a visual surface for present-day interviews with the Suri family about their feelings and perceptions in India.

5) Sandhya built historical footage from BBC archives into her film, such as 1960s educational programmes for immigrants which reveal the overtly patronising British attitude, and news reports from the 1970s and 1980s about expressions of anti-immigrant sentiment in Britain.

Sandhya claims that her aim in mixing the different forms was not to shock the audience with contrasts but to balance the material (Suri 2010, 2). However, from this technical description it already becomes clear that these five different kinds of material interfere with the dual (two stories of family life) and dialogical (questions and answers) narrative structure created originally by the Suri family exchanging letters between England and India, and complicate the question of authorship and voice in this film. Whose auto/biographical documentary is it?

The 'I' in I for India is Yash's, but his daughter Sandhya is the actual maker of the film, delivering her own version of her father's and family's life by selecting and arranging historical footage and adding her own. Thereby, she is not only the filmmaker but within the film, also an editornarrator of her family's films. In general terms, the film is the product of intergenerational collaboration and communication as well as narration. If treatment (or dramatisation, or interpretation) reflects "the documentarist's desire or willingness to use actuality material to create a dramatic narrative" (Winston 1995, 99), the question remains who is the documentarist and what role father and daughter (and others) play in the creation of a film that has been marketed as "a chronicle of immigration in sixties Britain and beyond". ${ }^{1}$

Alisa Lebow, in her brief study on I for India, focuses on "film as a diasporic apparatus" and argues that the conventionality of Yash's home videos is a means of inscribing himself in the technology, that he uses film to create the illusion of a personal presence across continents and occasionally delivers a kind of reverse ethnography of the strange customs in England (2012, 224-229). She also emphasises that "the epistolary film is a common trope in diasporic or so-called 'accented' cinema" and that I for India, with its uses of film letters and spoken, or telephonic, letters, falls into those categories (226). She reads the contradictions 
between the filmed material, which shows the happy moments of life, and the audio tapes which rather speak of the longings, regrets, doubts and crises that often mar diasporic life as an apt representation of the "cultural dysphoria" of diaspora (227). Finally, she finds the "shuttling back and forth of these contemporary migrations" ("hypermobility") closely linked with new visual and aural devices (new "technologies of connection") and characterises this and other films as "itinerant diasporic first person film[s]" (228-229).

While Lebow makes little of Sandhya's contribution to the meanings of the film, my own argument will depart from her focus on the nexus between diaspora and technologies of representation and rather foreground questions of authorship, the dialectic between the biographical and the autobiographical, and the function of the multiple voices and perspectives in this documentary. Furthermore, it needs to be discussed if and how this multiperspectivity is characteristic of a diasporic life narrative. Thus the theoretical framework of my investigation will cover, and link, diasporic life narratives and documentary films.

\section{AUTO/BIOGRAPHICAL DOCUMENTARIES AND MIGRATION}

Although there is a considerable body of academic writing about nonfiction films and filmmakers (Barsam 1995, 378), the special form of the autobiographical documentary has not yet received much attention from film scholars. Nevertheless, the production of autobiographical documentaries as well as scholarly interest in them have grown especially since the 1970 s, resulting in some publications mainly since the 2000s. ${ }^{2}$ Brian Winston observes a coincidence between the rise in the numbers of autobiographical films and an audience for them, the development of new technologies that allowed the shooting of synch sound films without a crew, and a Zeitgeist since the 1970s that was characterised by " 'a heightened interest in self-awareness, personal growth, family background, expanded consciousness and the human potential movement'" (Katz in Winston 1995, 202). Although he reports that several family-study films, often intergenerational and arising from crises, resulted from these changes, he also concludes that such films remained exceptional (203).

Because Yash was born and raised in India, it needs to be emphasised here that since independence, there has been a strong documentary tradition in Indian film, which has recently been further enriched by a number of first-person films and films that foreground the experience of the filmmaker (Barsam 1992, 372; Gadihoke 2012, 145-146). Yash and his family were thus familiar with nonfiction film and did not consider it an alien 'western' form and medium, unlike other filmmakers such 
as American Teshome Gabriel, for whom the camera "was a sign of his Westernisation" which he was unable to use in his native Ethiopia (Lebow 2012, 220).

After this brief historical introduction, I need to address the tension between the documentary as a supposedly (relatively) objective art form and the auto/biographical documentary as an avowedly subjective portrait of a person's life and environment. Jim Lane calls this the tension between "the documentary impulse to record a historical world 'out there' and [...] the auto/biographical impulse to subjectively record a private world 'in here'" $(2002,4)$. He also lists a number of features of auto/biographical documentaries as, for example, that authors are usually not public figures so that the audience has little preconception of their lives. They make films on a very low budget, and there are often no public records verifying the events that were recorded privately in nondescript locations such as their home (ibid.). All of this applies to Yash's footage in I for India. The list of features, though, raises the question of terminology since "home movie", "first-person film", "auto- or domestic ethnography" as well as some other terms (Lebow 2012, 6) have been used to describe this kind of material. Although Yash's films of birthday parties, trips and such events certainly are also subject of home movies, the special intention behind the cine-letters prohibits the use of this term. "First person film" would be too narrow, as will be shown in the discussion of multiperspectivity. Auto-ethnography certainly does not fully apply in the sense in which Mary Louise Pratt criticises it, that is, as a practice by which colonised subjects appropriate the coloniser's discursive models and blend them with indigenous knowledge to represent themselves (Smith and Watson 2010, 158). ${ }^{3}$ Even if Yash, born in the 1930s in India, might be considered a colonial subject, his cine-letters were not intended to talk back to the colonisers. However, the concept of auto-ethnography has also been used in a wider sense for life narratives that incorporate accounts of regional culture and group practices (ibid.) and thus may be applicable to some of Yash's footage, but, as will be shown, I for India is best described as an auto/biographical film in which several subjects represent themselves, but they also portray others and are portrayed by others.

In auto/biographical documentaries like Yash's, auto/biographical authority is achieved through the immediate, existential interaction with historical persons and events, producing an 'unofficial' history and overturning "popular conceptions of documentary as the purveyor of historical and scientific objectivity" (Lane 2002, 5). Auto/biographical documentaries "rely on narratives and micronarratives to present the course of a life" but often "lack the comprehensive narrative scope" of written 
auto/biographies (ibid.). Still, as Winston explains with regard to John Grierson's concept of "treatment", a true documentary dramatises the real (Winston 1995, 103). Lane also mentions that there has been a vast array of forms such as the journal entry, the family portrait and self-portrait documentaries. Nevertheless the auto/biographical documentary I for India does not easily fall into any such category. The function of the film's multiperspectivity will be discussed with regard to the construction of immigrant life narratives and the documentary genre.

\section{DIASPORIC AUTO/BIOGRAPHY}

The post-colonial situation, globalisation and the inequity of life chances in different parts of the world have, as has been widely acknowledged, resulted in substantial diasporas, of which the Indian diaspora is a prime example. Robin Cohen presents a list of common features of a diaspora, among which there are the dispersal or expansion from a homeland to two or more foreign regions, "a collective memory and myth about the homeland", an "idealization of the putative ancestral home", a return movement, a "strong ethnic group consciousness" as well as both a "troubled relationship with host societies" and the possibility of an enriching life in a - pluralistic - host community $(1996,515)$. These features of the diasporic situation have proven helpful in many analyses; and the multidirectional relationality of diaspora ${ }^{4}$ - to the homeland, to fellow expatriates and to the host society - is bound to shape self-representation and self-narration in recognisable ways.

Since decolonisation after the 2nd World War and then the 1990s, which brought the end of the Cold War and an upturn in globalisation, many persons left their native countries and settled in other countries, often far away, and these persons have in the past decades increasingly written and published auto/biographical texts, adding their subjective experiences and interpretations to the archives of publicly accessible knowledge, transforming these experiences into shared knowledge. Possible elements of diasporic life narratives are negotiations of the past (memory), often connected with justifications for leaving home; grappling with the new environment and negotiating one's place between the "two cultural systems" (Boelhower in Wong 1991, 144); settlement; actual return, return visits or the dream of return; and cultural transformation (including language).

There is already a substantial body of academic work on auto/biographical writing by migrants, immigrants, exiles and refugees, particularly in the United States (e.g. Eakin 1991; Hornung 2013). Furthermore, there have been attempts to define universal narrative patterns and structures 
of immigrant life narratives, but the diversity of forms has usually frustrated these attempts. ${ }^{5}$ However, Sau-ling Cynthia Wong's suggestion to consider the organisation of life narratives along various axes which correspond with the relations implied in Cohen's definition of diaspora, may prove a useful framework. Some issues from these - predominantly American - debates will be taken up with regard to the Indian diaspora in Britain.

One last factor resulting from the diasporic situation that deserves attention is the position of the auto/biographer as a mediator and translator. In different ways both the foreign-born first generation and the second generation born and raised in the host country may function as "knowledgeable insiders" (Wong 1991, 157) who are able to mediate between their intimate knowledge of their native or inherited culture and their at least partly western audiences' expectations and dominant discourses and knowledges. The auto/biographical documentary I for India offers itself for a case study of how different layers of time, authorship and representational strategies combine to construct a subjective narrative of migration and diaspora.

\section{MICRO- V. MACRO-NARRATIVES}

Lane claims that auto/biographical documentaries are characterised by the dominance of micro-narratives, and this holds fully true with regard to the cine-letters that the members of the Suri family exchanged, especially since each of their three-minute Super 8 films is rather self-contained and usually purely descriptive and observational. Here, footage of, for example, holidays, family gatherings, parties, weddings and a newlybought house provides the typical glimpses of the lives as they happen. They can also be interpreted as "signs of memory" (MacDougall 1998, 233-234), as attempts to create and maintain a shared family memory across the distance, along the axis between diaspora and home. Since, in one clip from India, Yash's relatives demand to see some funny scenes - and here the cutting and sequencing suggests a causal link to the later material -, the funny or at least happy scenes prevail among the clips of Super 8 footage. However, the individual Super 8 shorts are cine-letters, or home movies at best, and not an autobiographical documentary, which, if we follow Grierson's definition, would have a narrative unfold and would entail the dramatisation and interpretation of the material.

A clear narrative that includes dramatisation and interpretation is, nevertheless, added by Sandhya, who employs the first person footage and recordings as well as the other material mentioned above; through selecting and sequencing, she imposes a plot and creates a macro-narrative, 
which she outlines herself as "I - The yearning for home. II - The return to India. III - Back in England; the dream shattered", like a play in three acts ("I for India Interview"). Thus it is Sandhya who implements a dramatisation for which she draws the ideas and inspiration from her father, who himself says in one of his audio-commentaries that he, like others, "believ[ed] in the myth of return" (I for India DVD). The way Sandhya frames the narrative emphasises the story of her father's diasporic Indianness as expressed in the film title as well as his final statement:

"Please do not underestimate YPS with regard to his patriotism, his loyalty, no matter that he did not succeed in his own country, to resettle. The love for my soil hasn't diminished. I'm a true Indian." (English subtitles in the closing shot of the film; Fig. 2)

While showing a father who claims an Indianness undiminished by his failed attempt to resettle in India, Sandhya also underlines that the family's return to India was owed more to the emotional pressure which Yash's

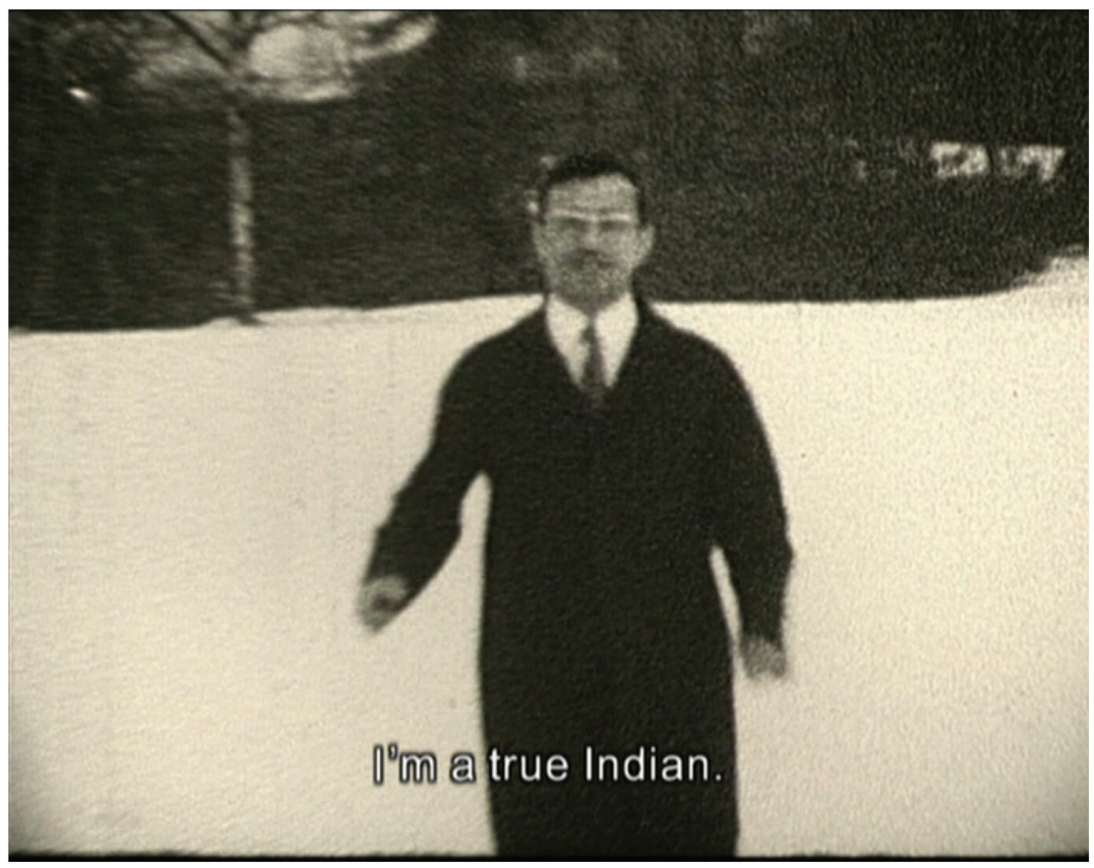

Figure 2: Closing shot: Yash in the snow. 
parents exerted on him than to his own wishes. In various places, Sandhya includes audio-letters of her aunt, uncle and grandparents in India from the 1970s urging Yash to return home, messages in which his mother draws vivid images of prosperity and success in India and confesses that she is praying for his return, and his father, crying, begs him, "My heart is breaking. I'm very distressed. Come home and I'll be better. What else is there left in my life? [...] I feel like dying." Through this, Sandhya documents an emotional pull that must have been unrelenting and forceful but carried in it the seed of failure. Seen from a different angle, Sandhya's inclusion of her grandparents' audio-letters assigns importance to the views and emotions of the family members left behind in India and memorialises their suffering under the separation, which distinguishes her film from others that focus entirely on life in the diasporic condition.

In this macro-narrative of her family's failed return to India, Sandhya includes her father's longing for home and feelings of guilt because he 'deserted' to England, abandoning his parents in India, and the film concludes with Yash's explicit attempt to assert his Indianness which he feels has become questionable due to the loss of its rootedness in Indian soil and society, that is, due to the de-territorialisation of Indianness in the diasporic situation.

The filmmaker/daughter made her father's story of Indianness and his unceasing but hopeless longing for home her own so that her father's and family's as well as her own perspectives are entangled in a way that they cannot, or only partly, be disentangled. She emphasised that she intended to create "something which was faithful to [her] parents' story" and selected the footage so that everything would "advance the narrative in some way" ("I for India Interview"). Clearly, she acts as a filmmaker-biographer who organises into a dramatic arc the story of other persons' lives with the help of visual and verbal autobiographical material produced by those persons. Another aspect of Sandhya's choice of the macro-narrative of failed return to India is that this story contradicts the popular British belief that all immigrants who entered the UK after the 2nd World War came with the intention to stay.

This implicit argument made in the main narrative is closely connected with a second narrative thread which establishes the axis between immigrant and host society and relates family history to public history, mainly to British history - there is very little Indian history -, through historical footage from BBC educational and news programmes. On the one hand, the selection of TV footage gives an account of the British responses to Indian and other immigrants, and these responses range from the patronising "educational" programme through a report on Indian doctors in England to an anti-immigration demonstration by the National Front and PM Margaret Thatcher talking about the British people fearing that they 
might be "swamped" by immigrants, documenting the xenophobic atmosphere of the 1970s and 1980s (Fig. 3). On the other hand, this footage functions as a tool of authentication and verification as it anchors Yash's life in British national history, substantiating his experience of the hardships of the beginnings and his frustration at not always being accepted. By slipping historical BBC footage in between the cine-letters, Sandhya also strengthens Yash's authority. The news clip with Thatcher justifying British anti-immigrant sentiment is followed by Yash's audio complaints about being corrected all the time and even being called a Paki, directly liking public political mood and Yash's experience of discrimination, merging public (TV-mediated) and intimate knowledge. However, these records of British hostilities do not directly precede, and thus not directly motivate, his return to India in 1982; rather, the motivation is provided through roughly 6 minutes of audio-letters from his family in India who talk of their distress and unhappiness, and who pressure Yash to come home, making him sleepless (visualised through Sandhya's own footage) from his guilt feelings, as the editing of the scenes suggests.

Although British anti-immigrant attitudes are not presented as the decisive factor for his and his family's return to India, they are closely connected with the macro-narrative of return. Thatcher's historic statement

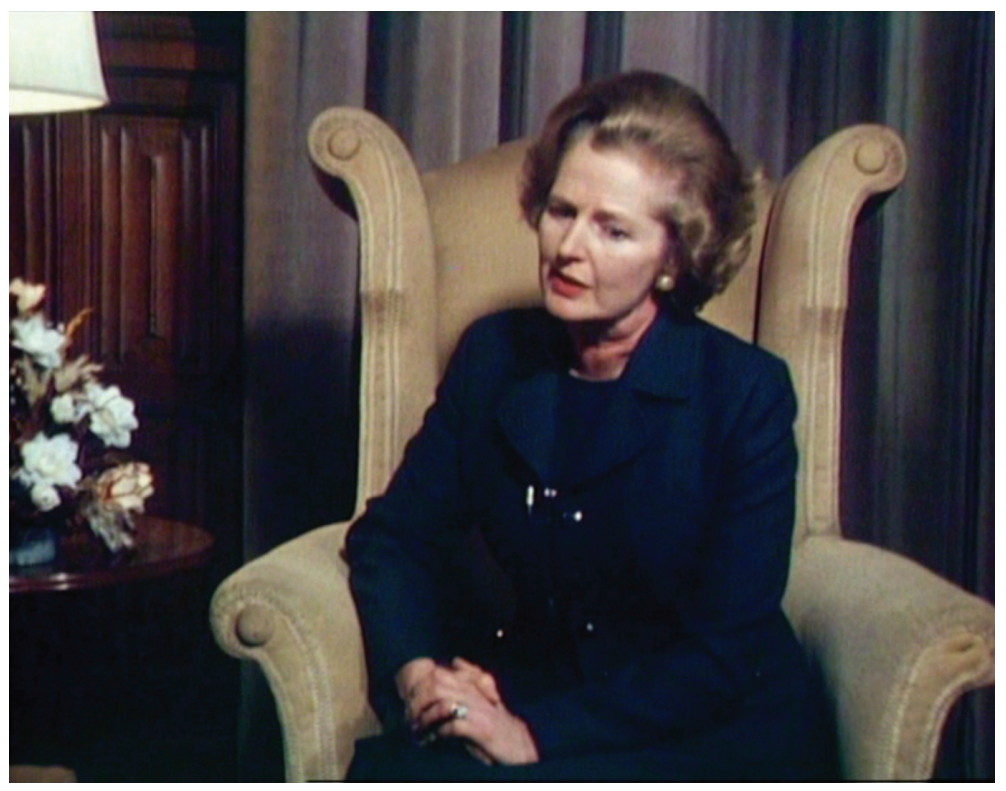

Figure 3: Margaret Thatcher. 
about British fears of immigrants which implied that the "Dark Million" (title of a news programme in the film) all came to stay is countered by Yash's longing for, and attempt to resettle in, India. In contrast to the main narrative of Indianness, which, in the end, confirms the persistence of conflicting loyalties, the second narrative suggests a positive resolution because the archival footage, in black-and-white and very dated language and visual styles, locates this kind of discrimination in the past, while Sandhya's own films on her family shot in the 2000s show a prosperous, culturally well-integrated and reasonably happy Indian British family.

A third narrative, beside the ones of Indianness maintained and of the public history behind the family history, deals with " $t]$ he identity crises of first-generation settlers", their "over-integration" and how forty years in England changed Sandhya's father, even made him lose his native language Hindi (Suri in Sandhu 2007). In one piece from an original audio-letter, Yash apologises to his parents for using English and promises to try "to find the comparable word in Hindi and not use the foreigners' language any more" (I for India DVD). Obviously, English had intruded in his previous messages to his parents, which they read as a sign of his linguistic drifting away from his native India and settling in England for good. This strand could also be called a narrative of acculturation, that is, of de- and re-culturation. In processes of de- and re-culturation, he gives up some practices of Indianness and instead increasingly adopts the English language, customs and way of life. The story of acculturation shows its protagonists fitting in and succeeding personally, professionally and economically; having their children grow up British and mix seemingly (in Yash's films) effortlessly with white British people. This story of "over-integration" is the organic counternarrative to the story of Indianness upheld, and to the decline of British anti-immigrant sentiments.

The three main narratives - of an Indianness maintained despite a failed return, of (declining) patronising and hostile attitudes in Britain and of successful integration in England - are deeply intertwined, informing, enhancing and contradicting each other. The way the different kinds of footage are sequenced makes them enter complex relations, as the material from the BBC archives authenticates Yash's story, gives it weight and links it to public history, but at times is also contradicted by Yash's accounts, as I have shown with regard to his return to India. Likewise, the predominantly happy scenes recorded in his cine-letters, the house parties and children's games also speak much more of successful integration than of the hostility highlighted by the news clips. These unresolved contradictions expressed along the various relational axes describe the position of the diasporic subject as in-between but continuously shifting. 


\section{THE STORY OF THE FAILED RE-SETTLEMENT IN INDIA AS AN} EXAMPLE OF MULTIPERSPECTIVITY

Beside the dramatic interplay between Yash's yearning and resistance, and the powerful pressure from his parents to return, the re-construction of the family's actual nine-month return deserves attention as a prime example of the interplay of perspectives, images and voices across time. The journey is located exactly in time, "5th February 1982," and starts with the well-known symbol of migration, the airplane,${ }^{6}$ then shows, in colour, relatively non-descript scenes of street life, school children, traffic (Fig. 4), the interior of a house. The whole section set in India lasts about 16 minutes (00:36:15-00:52:00), which is a substantial part of the 70-minute film. Because Yash did not film cine-letters any more after his return to Meerut, Sandhya had to have her family reconstruct that time in retrospective. She builds this part of the narrative from interviews with her mother, father and two sisters, interspersed with more footage

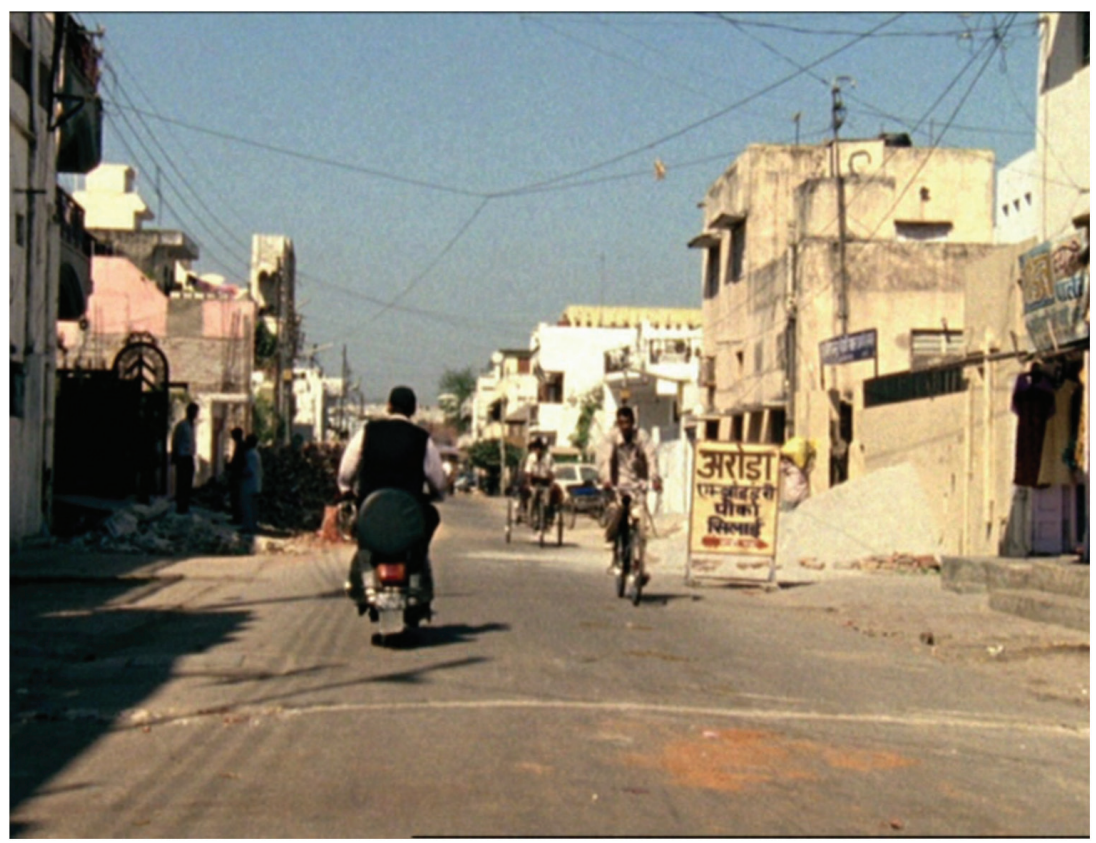

Figure 4: Street scene in contemporary India. 
about Indian life. The different family members provide different views on the experience. Yash's wife, Susheel, talks about Yash's initial happiness and enthusiasm, but also about the house being crowded at their arrival because of a wedding and about "three families living under the same roof", which she "didn't like very much," and about being "not too happy". Sandhya's sister Vanita remembers that the best thing was that she did not feel "like a misfit" like in England, remembering, "I looked the same, I wore the same clothes" and more similarities, concluding, "I felt really at home." Her sister Neeraj, who had gone to India a year before the family in order to go to college, found university life dull and mundane compared with life in England and felt stifled by restrictions on Indian girls' behaviour.

The interviews with Yash's wife (Fig. 5) and daughters also contain comments on his decision, providing biographical information. Susheel tells Sandhya that she noticed how, after his initial optimism, "your father had a difficult time" and got irritable. His daughter Vanita muses that he was not prepared to have such a "mediocre career and mediocre life style" in India for the sake of being with his family so that, after nine months, the family decided to return to England.

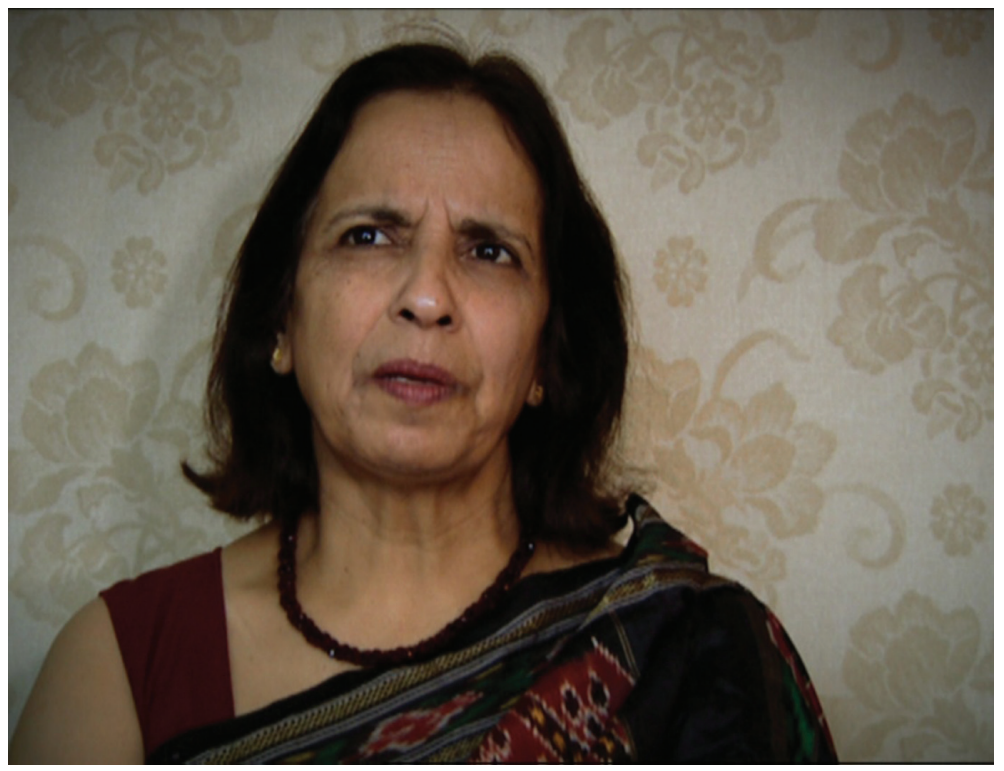

Figure 5: Susheel being interviewed by her daughter Sandhya. 
Yash himself, in an interview in 2003, remembers how great it felt to be back and how optimistic he was, quoting Tom Jones's song line of "the green green grass of home". Consequently, the failure of his clinic is not admitted by him but described - euphemistically - by one of his daughters who quite often went to her father's clinic and found it empty, her father "sitting alone in this little hut, it was quite sad" compared with his life in the big English hospital where "he was a man of standing." Susheel adds that some people questioned Yash the British specialist's understanding of "how to treat patients here." Scenes in which an Indian street vendor entertainingly praises his miracle cures and love potions to a male audience heighten the contrast between Indian folk medicine and Yash's British approach. Sandhya finally uses an audio-recording of October 1982 in which Yash speaks in Hindi about his love for and, mainly, his estrangement from India, wondering, for example, "how strange our people are," and complaining that many Indians lacked helpfulness and were "only interested in earning money, by fair or foul means". His long tirade of bitter disappointment also implies a justification of his decision to return to England. It is visually underlined by scenes of police action, poverty, the demolition of a house and construction work. The section ends very poetically with two and a half minutes of footage of the flow of traffic - everybody is in motion, the camera moves with the flow, and a popular Bollywood song by famous Geeta Dutt intensifies the atmosphere of restless movement by talking of "restless hearts", parting and being lost.

In this narrative of failed re-settlement, various subjective perspectives are combined into a web of emotions, experiences, observations and their interpretations, which also reveals different types of returning migrants' responses such as the discovery of a strong sense of familial or ethnic belonging but also alienation, disillusionment and loss of personal freedom. Biographical and autobiographical statements complement each other in this part of the family's history and contribute to a multifaceted depiction, which, again, reflects those various axes of connectedness that characterise diaspora, and which do not dissolve at the moment of return but are re-configurated.

\section{THE DOCUMENTARY GENRE, AUTO/BIOGRAPHICAL "I"S AND THE EXEMPLARY LIFE}

As has become clear in the previous section, the different narratives are closely connected with different auto/biographical "I"s. Although I stated earlier that I for India does not fully meet the expectations of a first person film if the latter is understood in a narrow sense as an ego-driven 
self-representation of the filmmaker, it is possible to apply the term in the wider sense as "mode of address" and a film that speaks "from the articulated point of view of the filmmaker who readily acknowledges her subjective position", which can be done in the first person singular or plural (Lebow 2012, 1). However, even this wide definition does not fully account for the complexity of authorship and the (various) first person(s) in the film. The multiplicity of viewpoints is rooted in the film being the product of intergenerational collaboration and communication, which is a major thread in the social fabric of diaspora. The relevance of the anticipation of audience expectations shows in the emphasis that is placed on the ambiguous "I" that alludes to both India and Yash's voice in his 'home video' footage and promises an eyewitness's historical account of the migration experience. Nevertheless, the front cover of the DVD features a typical tourist shot of two daughters at a young age in London with a sentry of the Queen's Guard, visually hinting at the daughters' presence in the narrative.

As Sandhya compiled the story of her own family, she occasionally appears in the footage. It can be concluded that beside her visual presence, the act of re-telling her family's story implies her own presence in their stories. Thus her position oscillates between being the documentarist who records, reconstructs and interprets other people's lives (in the footage shot by herself and through her work as the director), and being a protagonist depicted in some footage of her father's memories. By including some footage of herself, she assigns herself a place in her family's story of migration and acculturation, which makes the film biographical (her father's recording of her life) and autobiographical at the same time, and this duality of representation can be found with regard to herself as well as her father and other family members. The biographical aspect of the film is particularly apparent when she films her father while he himself is filming his family at the airport, seeing off his daughter Vanita (Fig. 6).

Although Yash's cine- and audio-letters and incidents of family life as told by himself provide the backbone of the narrative and do contain some statements, especially on the audio-tapes, in which he 'speaks directly' and tries to reveal his inner life, the film is not just a compilation of auto/ biographical Super 8 material and audio-commentaries, nor is it a selfportrait in the first place. Rather, it provides a wider view on diasporic life from the 1960s in England and also assigns Yash and his family's life story an exemplary dimension, which he himself suggests in his concluding commentary in the film by saying that "our youngsters will gain a lot of insight from it about the early struggles". Yash's auto/biographical narrative acquires special historical documentary value because it was shot in the 1960s, 1970s, 1980s and so on, and not in retrospective. Therefore 


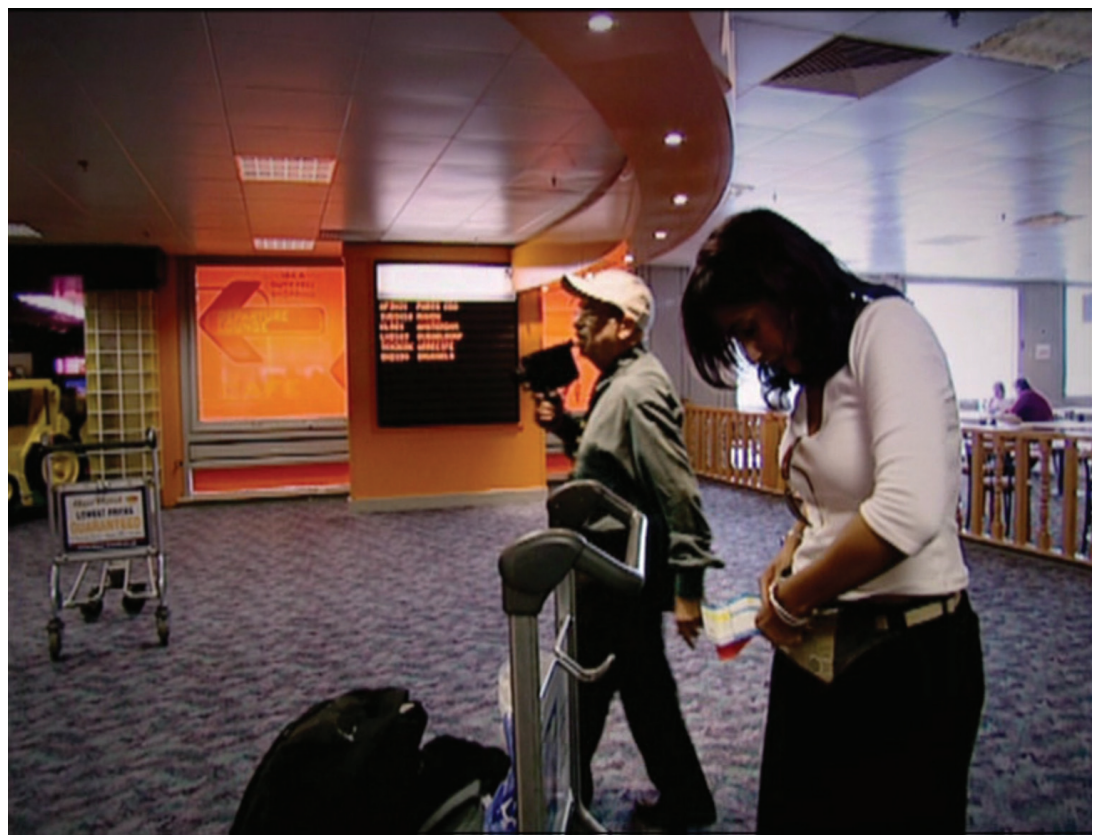

Figure 6: At the airport in the 2000s.

it is also presented, and received, as an eyewitness's account of his social group's - migrant Indian professionals in post-war Britain - historical struggle that, through the exemplary character of the family's life, can teach posterity. As a documentarian and biographer, Sandhya fully agrees with her father's concept of the exemplary life narrative to learn from as she embeds her family's story in public history so that it has "a bigger feel about it rather than just my family" ("Interview with Sandhya Suri").

As a documentarian in the new millennium, however, she does not pretend that her film is 'objective' and that she is emotionally unattached to the people in the film, but she combines observational footage with interactive parts such as interviews (Buckland 2003, 137-141). Her presence is inscribed in the interviews when her parents address her directly, speaking of "your father" and "your mother", assigning her a place in their discourses although she remains invisible in these scenes. She also inscribes herself into the film at the end, when she films her own image on the computer screen skyping with her sister in Australia, thus commenting visually on her own active involvement and presence in the family's history. 


\section{CONCLUSION}

In I for India, Sandhya Suri's second-generation perspective controls the main narrative, which evolves around the cultural themes of identity (crisis), language loss, in-betweenness, strained family ties and an imagined 'essential' Indianness under the conditions of diaspora. The use of the same black-and-white Super 8 footage of Yash in the snow for the opening and closing shots of the film makes the story of his Indianness a circular one in which his initial foreignness in cold England is repeated and confirmed visually and verbally at the end: "I'm a true Indian". To some extent, this ending overrides all other stories and affirms Yash's diasporic Indian nationalism and the axis connecting him with home. On the one hand, his adherence to a nationalist ideology fails to smooth the shifts and fractions of identity in his life but instead reveals its contingencies. On the other hand, his presumably unchangeable Indianness still allows a story of successful "over-integration" to unfold within its limits, despite various incidents of his painful experience of otherness. These contradictions and ambiguities appear to be closely connected with the diasporic situation which, in many cases of first-generation immigrants, produces both a developmental narrative of acculturation and circular narrative of a stable core of loyalty to their native country, which is characteristic of the diasporic dilemma of belonging. In this case, though, it is the secondgeneration director who builds the story with hindsight, thereby distancing herself from her father's identity issues but also admitting her auto/ biographical involvement in his struggles.

Despite and because of its focus on Yash's identity struggles, the film brings multiple voices and perspectives into play that range from the various "I"s of the micro-narratives and observations in the Suri family's 'home movies' to the British perspectives on immigrants - of educators, biased news programmes, racist organisations to Margaret Thatcher and to Sandhya's own footage of her family talking about themselves in the 2000s. Although one could presume that I for India belongs to the common type of documentaries which record different voices and points of view on one particular social, political or cultural issue, and although this category establishes its claim of impartiality or 'objectivity' through the multiplicity of perspectives, the film also differs significantly from this type through the use of voices recorded over a long time span and the intended emotionality and subjectivity of the bulk of the footage on which the narrative is built - and that narrative, dramatic quality of the film also sets it apart from non-fiction films that only juxtapose different people's opinions. All of these voices are arranged along the various axes of diasporic relatedness, plus the axis of intergenerational entanglement. 
The form of the film does not only reflect the particular archives, private and public, which Sandhya had at her disposal but also the different subjectivities that shape the diasporic condition of her family and diaspora in general.

The opening and closing shots on grainy black and white Super 8 material of Yash running through the snow in England may, as Lebow does, be read as implying a statement about the mobility of the cinematic apparatus, but it may also be understood as a visual sign of diasporic identities being suspended between places and remaining unsettled and dynamic. The scenes of Yash's daughter Vanita leaving England for Australia illustrate that the spreading of the Indian diaspora has by no means stopped. Furthermore, the scene of the conversation on skype between Vanita and her parents and sister in England marks a change of the media that facilitate and record the contact between diaspora and home, and indicates that the meaning of 'home' changes for each generation. Here as in most of the film's material, the inextricable entanglement of persons and places, of view points and longings are shown to make up the core of the diasporic condition of life.

\section{WORKS CITED}

Barsam, Richard M. Nonfiction Film: A Critical History. Rev. and expanded ed. Bloomington: Indiana UP, 1992. Print.

Buckland, Warren. Film Studies. London: Hodder, 2003. Print.

Cohen, Robin. "Diasporas and the Nation-State: From Victims to Challengers." International Affairs 72.3 (1996): 507-520. Web.

Eakin, Paul John (ed.). American Autobiography: Retrospect and Prospect. Madison, Wis.: U Wisconsin P, 1991. Print.

Gadihoke, Sabeena. "Secrets and Inner Voices: The Self and Subjectivity in Contemporary Indian Documentary." Ed. Alisa Lebow. The Cinema of Me: The Self and Subjectivity in First Person Documentary. London: Wallflower Press, 2012. 144-157. Print.

Hornung, Alfred (ed.). American Lives. Heidelberg: Universitätsverlag Winter, 2013. Print.

I for India. Dir. Sandhya Suri. 2005. DVD. ICA Films 2007.

"I for India Interview." 7inch Cinema. Not dated. Web. 18.10.2013.

"Interview with Sandhya Suri." 27 August 2007. Electric Sheep Magazine. Web. 18.10.2013.

Lane, Jim. The Auto/Biographical Documentary in America. Madison, Wis.: U Wisconsin P, 2002. Print.

Lebow, Alisa. 'Introduction.' Ed. Alisa Lebow. The Cinema of Me: The Self and Subjectivity in First Person Documentary. London: Wallflower Press, 2012. 1-11. Print.

Lebow, Alisa. "The Camera as Peripatetic Migration Machine." Ed. Alisa Lebow. The Cinema of Me: The Self and Subjectivity in First Person Documentary. London: Wallflower Press, 2012. 219-232. Print.

MacDougall, David. Transcultural Cinema. Princeton, N.J.: Princeton UP, 1998. Print.

Martin-Jones, David. Scotland - Global Cinema. Genres, Modes and Identities. Edinburgh: Edinburgh UP, 2009. Print.

Mississippi Masala. Dir. Mira Nair. 1991. DVD. Ufa Home Entertainment 2005. 
Sandhu, Sukhdev. "The Past Is a Foreign Country." 21 July 2007. The Telegraph, Web. 18 October 2013.

Smith, Sidonie and Julia Watson. Reading Autobiography: A Guide for Interpreting Life Narratives. 2nd ed. Minneapolis: U Minnesota P., 2010. Print.

Suri, Sandhya. "Interview." Published in Spanish in Cuevas Àlvarez, Efrén (ed.), La casa abierta. El cine doméstico y sus reciclajes contemporáneos. Madrid: Ocho y Medio, 2010. 387-391. Web. 18 October 2013.

Winston, Brian. Claiming the Real: The Documentary Film Revisited. London: bfi, 1995. Print.

Wong, Sau-ling Cynthia. "Immigrant Autobiography: Some Questions of Definition and Approach." Ed. Paul John Eakin. American Autobiography: Retrospect and Prospect. Madison, Wis.: U Wisconsin P, 1991. 142-170. Print.

\section{ABOUT THE AUTHOR}

Gabriele Linke is a professor for British and American Cultural Studies at the University of Rostock. Her recent research and writing have covered mainly three areas, which are contemporary autobiographical writing, (transnational) film studies, and theories and methods of teaching culture (ed. Teaching Cultural Studies, 2011).

\section{NOTES}

1 Quotation from the blurb on the back cover of the DVD.

2 For a summary of the literature on the autobiographical or first person film, home movie, auto-ethnography etc., see Lebow (2012, 6, 10-11).

3 Martin-Jones $(2009,17)$ also criticises that auto-ethnography in cinema has been used to "self-consciously 'auto-exoticise" " and sell back to mainstream audiences the stereotypes that had initially been produced by mainstream culture.

4 Wong $(1991,160)$ calls this multidirectionality "multiple, provisional axes of organisation".

5 Wong (1991) argues against the idea of a universal macrostructure of American immigrant autobiographies and for the acknowledgement of great variation along various axes of organisation and classification.

6 A particularly clear example can be found in Mira Nair's film Mississippi Masala, where an Indian family's escape from Uganda involves an emotional parting scene at the airport and a map with their route to the United States.

7 These and all other quotations have been taken from I for India (DVD). 